Golden Gate University School of Law GGU Law Digital Commons

Fall 2006

\title{
United States Migration Law: Essentials For Comparison
}

\author{
Christian N. Okeke \\ Golden Gate University School of Law, cokeke@ggu.edu \\ James A.R. Nafziger
}

Follow this and additional works at: http:// digitalcommons.law.ggu.edu/pubs

Part of the Immigration Law Commons

\section{Recommended Citation}

54 Am. J. of Comp. Law Supp. 531 (2006)

This Article is brought to you for free and open access by the Faculty Scholarship at GGU Law Digital Commons. It has been accepted for inclusion in

Publications by an authorized administrator of GGU Law Digital Commons. For more information, please contact jfischer@ggu.edu. 


\title{
UNITED STATES MIGRATION LAW: ESSENTIALS FOR COMPARISON
}

\section{CHRIS NWACHUKWU OKEKE \\ JAMES A.R. NAFZIGER}

\author{
Reprinted from \\ The American Journal of Comparative Law \\ Volume LIV, Fall 2006, Supplement \\ Copyright $\odot 2006$ by the American Society of Comparative Law, Inc.
}




\section{CHRIS NWACHUKWU OKEKE*}

JAMES A.R. NAFZIGER**

\section{United States Migration Law: Essentials for Comparison***}

\section{INTRODUCTION}

Few issues have commanded more sustained attention among scholars, practitioners, and policymakers than the legal position of migrants at both national and international levels. It is certainly a topical issue, having gained more prominence and potency in the United States since the "9/11" terrorist attacks of September 11, 2001.

Despite the global focus on terrorist infiltration across national boundaries, the motivation of most migrants is well-intentioned. Around the world today, millions of people are on the move, for good reasons, living or trying to live in countries not their own. About 175 million people today reside outside the country of their birth or nationality. The impetus for this unprecedented movement is varied. Sometimes the movement is voluntary. People move across borders for work, education, pleasure, curiosity, or family reasons. Migration also may be forced, as people flee across national borders for reasons of civil unrest, war, natural catastrophes, and famine. In recent years, the internal displacement of people within their own states also has accelerated.

Migration often generates tensions. Refugee movements, in particular, are often sudden and substantial. In destination countries, the public response is normally tolerant. Sometimes, however, mi-

* Associate Professor of International \& Comparative Law, and Co-Director of the Center for Advanced International Legal Studies, Golden Gate University School of Law.

** Thomas B. Stoel Professor of Law and Director of International Programs, Willamette University College of Law. Professor Nafziger has served as a consultant on migration law to the governments of Albania, Kazakhstan, Kyrgyzstan, Turkmenistan, and Uzbekistan. For a comparative study based partly on these projects, see James A.R. Nafziger, A Comparison of Processes for Reforming Migration Laws in Transitional States: China, Kazakhstan, and Albania, 70 WASH. L. REv. 757 (1995). *** This article was prepared as the United States report on "The Legal Position of Migrants" for presentation at the 17th Congress of the International Academy of Comparative Law in Utrecht, The Netherlands, July 16-22, 2006. It is part of the collection of United States reports that was published as a quadrennial Supplement to the American Journal of Comparative Law. 
grants are greeted with hostility or outright rejection. They may be treated as scapegoats for the ills of society and subjected to differential treatment and abuse. Such attitudes seem reprehensible but may be understandable whenever, as so often happens, the brunt of mass migration must be borne by impoverished states unable to absorb new settlers.

It would be difficult to exaggerate the historical significance of migration to the United States, particularly during the late nineteenth and early twentieth centuries, as the country pushed westward in its manifest destiny. Strong "push" factors impelled waves of migrants to leave states of origin just as "pull" factors attracted them to the United States. American literature abounds in the stories of immigrants, told by Willa Cather, Ole Rölvaag, John Steinbeck, E.L. Doctorow, and others. As is so frequently said, the United States is a nation of immigrants.

The immigration and nationality law of the United States is complex. It is more the product of historical experience than logical design. In one memorable, often-quoted simile, the law bears "a striking resemblance" to "King Minos's labyrinth in ancient Crete."1 Perhaps only the internal revenue (tax) code and its voluminous regulations are more intricate. Given this complexity, we can only summarize United States migration law. ${ }^{2}$ The purpose of this article, as part of a transnational dialogue, is to locate the migration law of the United States within the framework of international migration law and to highlight the essential features of the United States law for comparison. We begin with an identification of the international legal framework that pertains to the United States. We then turn to the characteristics and trends of United States immigration law, concluding with a summary of the law governing the treatment of migrants residing in the United States.

\section{The Position of Migrants Under International Law}

\section{A. The Refugee Convention}

The United States is a party to several treaties addressed to issues of migration. Chief among these is the 1967 Protocol to the 1951 Convention on the Status of Refugees (the Refugee Convention). Accordingly, the country is bound by the requirements of that Convention, including its definition of a refugee, its injunction against refoulement of persons to destinations where they would face perse-

1. Lok v. Immigr. \& Naturalization Serv., 548 F.2d 37, 38 (2d Cir. 1977).

2. In keeping with the authors' efforts to simplify this article within the space limitations for its publication, we have kept footnoting to a minimum and have avoided pin-point citations. For example, we have cited only those treaties to which the United States is not a party. All treaties to which the United States is a party may be found in U.S. Dep't of State, Treaties in Force (2005). 
cution, and its requirements for treatment of refugees. The federal government divides prospective refugees into two categories: overseas refugees, normally lodged by nationality groups in foreign camps under the supervision of the United Nations High Commissioner for Refugees or other recognized authority; and individual asylees, who seek political or other asylum within the Refugee Convention's definition of a refugee, as incorporated into federal law since 1980.

Under the Refugee Convention, a refugee is any person with a well-founded fear of persecution for reasons of race, religion, nationality, membership in a particular social group, or political opinion. Of these five bases for refugee status, two bases-political opinion and membership in a social group-have dominated policymaking, administrative decisions, and litigation in the United States.

The federal government, in reviewing the eligibility of prospective refugees on a case-by-case basis, has broadened the definition of a refugee to include such "social groups" as African women fleeing tribal practices of female circumcision or genital mutilation and homosexuals fleeing persecution. Foreign policy, too, has tempered interpretation of the definition of "political opinion." Until recently, for example, federal law entitled most migrants from Fidel Castro's Cuba - many of them "boat people"-to refugee status. On the other hand, Haitian "boat people" have found it difficult to avoid interdiction in the Caribbean Sea and return to Haiti by the United States Coast Guard.

In the instance of overseas refugees, the United States has agreed, as a matter of international solidarity, to cooperate in the relocation of groups of persons defined by their countries of origin and location of temporary encampment. Accordingly, the President determines an annual quota for each source region of eligible overseas refugees. The criteria for establishing the status of overseas refugees are therefore less individualized than those for asylees. Overseas refugees constitute the overwhelming majority of the more than 50,000 to 100,000 refugees who are normally admitted into the United States each year. The total number of refugees declined significantly, however, in the quarter century between 1980, when Congress enacted legislation under the Refugee Convention, and 2005.

\section{B. Other Instruments}

The United States is a party to several other migration-related instruments, of which three are noteworthy. The Constitution of the Intergovernmental Committee for Migration requires the United States to cooperate in the law-making and implementing work of that organization. Its projects have ranged from legal and other technical assistance in specific countries to broader efforts to encourage equitable redistribution and resettlement of migrants. The United States is 
also party to the Convention against Torture and Other Cruel, Inhuman or Degrading Treatment or Punishment, which protects all persons, including migrants, from removal to countries where they may be subject to torture. The Convention against Torture plays a particularly important role in defining the status of migrants for purposes of admission and protecting them from injurious refoulement.

The United Nations Covenant on Civil and Political Rights, to which the United States is a party, establishes basic rights to leave any country and to return to one's own country. These rights are subject only to restrictions necessary to protect national security, public order, public health or morals, or the rights and freedoms of others and which are consistent with the other rights recognized in the Covenant. In practice, the Covenant is non-self-executing under United States law and therefore requires implementing legislation that, if it existed, would give persons standing to invoke its provisions. In effect, however, the rights enshrined in the Covenant, to which migrants and others are entitled, are seldom controversial in the United States. To be sure, the country does exercise its power to exclude returning lawful permanent residents (LPRs). One might argue that an LPR's "own country" is that of his or her residence or domicile, but the right to return is normally interpreted to require citizenshipthat is, to identify "one's own country" as the country of which one is a citizen or national.

\section{International Custom}

The United States has accepted the general practice of a state's qualified duty to admit aliens when they pose no serious danger to its public safety, security, general welfare, or essential institutions. A regulated openness to migrants reflects an opinio juris of the global community. In reality, very few states that are potentially attractive to migrants bar admission in the name of sovereign prerogative. Within margins of appreciation, therefore, the United States has not adhered to judicial and other pronouncements of an unfettered "sovereign" competence to bar immigration. ${ }^{3}$

Even the principal Supreme Court opinions ${ }^{4}$ of the late nineteenth century that are cited to support extravagant claims of "sover-

3. See generally James A.R. Nafziger, The General Admission of Aliens Under International Law, 77 AM. J. INT'L L. 804 (1983); accord, RichaRd Plender, InTERNATIONAL Migration Law xiv (2d ed. 1988) ("dispelling the notion that the control of nationality and migration falls within the reserved domain [of the sovereign state]. The qualifications that need to be made to that assertion are now so clear that they speak for themselves.").

4. See Chae Chang Ping v. United States (The Chinese Exclusion Clause), 130 U.S. 581, 609 (1889) ("The power of exclusion of foreigners being an incident of sovereignty belonging to the government of the United States . . . cannot be granted away or restrained on behalf of any one."); Nishimura Ekiu v. United States, 142 U.S. 651, 659 (1892) ("It is an accepted maxim of international law, that every sovereign nation 
eign" authority to bar all immigration are themselves qualified. 5 To the extent that these opinions can be interpreted to adopt an unqualified restrictionist premise, they contradicted the best evidence of current norms of international law. In 1892, precisely when the controversial Supreme Court opinions were issued, the Institute of International Law adopted International Regulations on the Admission and Expulsion of Aliens. These Regulations confirmed in some specificity the principle of due regard for the historic right of migrants to enter a foreign state's territory to the extent compatible with that state's security. ${ }^{6}$ Terrorist threats, of course, present the most poignant example of exceptions to the qualified duty to cooperate in the process of migration and sensible resettlement of migrants.

has the power, as inherent in sovereignty, and essential to self-preservation, to forbid entrance of foreigners within its dominions, or to admit them only in such cases and upon such conditions as it may see fit to prescribe."); Fong Yue Ting v. United States, 159 U.S. 698, 705-07 (1893) ("it is an accepted maxim of international law that every sovereign nation has the power, as inherent in sovereignty, and essential to self-preservation, to conditionally admit or expel foreigners.").

5. In sum, even a strict constitutional constructionist could find little compulsion in the case law for the proposition that a state may exclude all aliens absolutely. Three of the four leading opinions are nearly a hundred years old, three applied exclusion doctrines principally to uphold racial or ideological tests acceptable then but questionable today, and one misapplied cited authority. Moreover, three of the four opinions predated comprehensive immigration laws, and therefore may have gone as far as they did in lieu of broad statutory rules. Most importantly, the definitive opinions in The Chinese Exclusion Case and Fong Yue Ting qualified the excludability of aliens by citing international legal authority to the effect that a state can exclude aliens only when they present a danger to the peace and security of the country. Subsequent opinions that failed to acknowledge this limitation on sovereign power mostly addressed other issues such as the allocation of powers among branches of the federal Government. Reaffirmations of the exclusive power of the political branches of government to make rules for the admission of aliens have been "legion." Other opinions relied upon semantic distinction, since discarded, between a right and a privilege, or, as in Kleindienst $v$. Mandel, simply failed to cite precedent contextually, completely, and correctly.

Nafziger, supra note 3 , at 828.

6. ARTicle 6. Free entrance of aliens to the territory of a civilized State may not be generally and permanently forbidden except in the public interest and for very serious reasons, for example, because of fundamental differences in customs or civilization, or because of a dangerous organization or gathering of aliens who come in great numbers . . .

ARTICLE 7. The protection of national labor is not, in itself, a sufficient reason for non-admission. . . .

ARTICLE 12. Entrance to a country may be forbidden to any alien individual in a condition of vagabondage or beggary, or suffering from a malady liable to endanger the public health, or strongly suspected of serious offenses committed abroad against the life or health of human beings or against public property or faith, as well as to aliens who have been convicted of the said offenses.

12 Inst. Droit InT'l ANNUAIRe 218 et seq. (1892-94). For minutes of the proceedings convened to draft the regulations, see id. at 184-218. For an English translation of the regulations, see RESOLUTIONS OF THE INSTITUTE OF INTERNATIONAL LAW 104 et seq. (J. Scott ed. 1916). 
The strength of international custom is apparent in judicial pronouncements holding that the prohibition of torture is jus cogens, no derogation from which is permitted regardless of a state's obligations under the Convention against Torture. Custom is also effective in helping ensure compliance with basic rules of international humanitarian law, as we shall see in the next section of this article.

\section{Lex Ferenda: Internally Displaced Persons}

The plight of internally displaced persons (IDPs)—those persons fleeing particular circumstances but unable to escape across a national boundary-has only recently come within the purview of international law. A protective regime is emerging, but it is still lex ferenda. This body of soft law may be summarized as follows.

Two instruments articulate basic expectations about the treatment of IDPs. These expectations are rooted in the law of human rights, humanitarian law, and refugee law. The two instruments are the Guiding Principles on Internal Displacement (Guiding Principles), which were developed by the Representative of the United Nations Secretary-General on IDPs, and the London Declaration of International Law Principles on Internally Displaced Persons (London Declaration), which was adopted by the International Law Association. ${ }^{7}$ The London Declaration has been submitted to governments and international organizations for their consideration and possible adoption.

Of these two instruments, the London Declaration is broader and more recent. As we shall see, it also is unique in addressing the needs of victims of natural disasters such as the devastating earthquakes and tsunamis in Asia (2004), hurricanes in the United States (2005), and earthquake in South Asia (2005).

The London Declaration contains eighteen articles that set forth rights and obligations pertaining to IDPs for all states, de facto authorities, the United Nations, and other organizations, both governmental and nongovernmental. These articles establish a regime of protection that includes minimum standards of treatment, requirements for international cooperation, and supervision by international authority. The London Declaration also includes substantial articleby-article comments. An extensive definition of IDPs includes

persons or groups of persons who have been forced to flee or leave their homes or places of habitual residence as a result of armed conflict, internal strife or systematic violations of

7. The London Declaration was drafted by a committee of the International Law Association chaired by Dr. Luke T. Lee. The co-rapporteurs were Rainer Hofmann and Yukio Shimada. This description of the London Declaration is drawn from a fuller account written by Dr. Lee and Professor Nafziger, in the ABILA Newsletter, No. 60, Feb. 2001, at 2. 
human rights, and who have not crossed an internationally recognized State border. This Declaration applies also to persons internally displaced by whatever causes, such as natural or man-made disasters or large-scale developmental projects, whenever the responsible State or de facto authority fails, for reasons that violate fundamental human rights, to protect and assist those victims.

The London Declaration takes note of the Guiding Principles. Unlike the latter, however, the London Declaration highlights the unique status of IDPs as de facto refugees confined in their national territories and therefore in need of a special protective regime. As already noted, the London Declaration also adopts a new and broader definition of IDPs and extends beyond the limited scope of the Guiding Principles to deal with a number of difficult issues. These include the status of safe areas, the prevention of reverse ethnic cleansing, institutional arrangements to provide protection and assistance to IDPs, and a definition of the Security Council's role when internal displacement amounts to a threat to international peace and security. In its final report, the ILA Committee on Internally Displaced Persons noted that an international organization, such as the United Nations High Commissioner for Refugees, could be designated or a new one established, to assume the responsibility of protecting and assisting all displaced persons-both refugees and IDPs.

The extent to which the London Declaration and the Guiding Principles codify general practice, on one hand, or can serve only to progressively develop practice in the United States, on the other hand, is unclear. A pathfinding study of customary international humanitarian law by the International Committee of the Red Cross ${ }^{8}$ disclosed several important rules of general practice on behalf of IDPs in time of armed conflict. These rules include non-deportability of IDPs from occupied territory; minimum conditions of shelter, hygiene, health, safety, nutrition, and avoidance of separation among family members; the right to voluntary return; and property rights.

United States practice is somewhat mixed. For example, during the American military occupation of Iraq, the customary rules for protecting IDPs were generally well-respected despite the chaos of war. During natural disasters within the United States, however, the protection of IDPs may have been somewhat compromised. When, in 2005, Hurricanes Katrina and Rita generated mass displacement in Louisiana and Texas, it became questionable whether the United States was as fully prepared or responsive as it should have been in compliance with the expectations of the London Decla-

8. International CommitTee of the Red Cross, I Customary International Humanitarian Law 457-75 (Jean-Marie Henckaerts \& Louise Doswald-Beck eds. 2005). 
ration. The official responses by national, state, and local governments appear to have been confused and delayed in the instance of Katrina but greatly improved and effective a month later when the less devastating Rita ripped through the same coastal region of the country. Despite the deficiencies of disaster relief after Hurricane Katrina, however, it is clear that, within the London Declaration's definition of an IDP, the United States did not "fail for reasons that violate fundamental human rights to protect and assist" the victims. Although the vast majority of the IDPs were African-Americans, claims of racism generally proved to be groundless.

It is also clear that the global community responded well to the hurricane disasters, just as it had in late 2004 and early 2005 in response to the devastating tsunamis in Asia. This evidence of global solidarity offers promise that the provisions of the London Declaration, in the wake of natural disasters, at least, may eventually articulate a general practice of prompt and effective relief as a matter of global solidarity.

\section{E. Definition of a "Migrant"}

One lay definition of the term "migrant" can be understood to mean, quite simply, a person who lives temporarily or permanently in the territory of a state other than that of the person's origin or nationality. Sometimes the migrant has acquired significant social ties to a foreign state of migration, other times not. A narrower definition, perhaps contemplating seasonal movement of workers within a single country rather than international resettlement, defines a "migrant" as one who moves frequently to find work. Given this variation, it will be instructive to consider two authoritative definitions of the term in the international system.

The United Nations Convention on the Rights of All Migrant Workers and Members of Their Families (Convention on Migrant Workers), which entered into force July 1, 2003 but to which the United States is not a party, defines a migrant worker restrictively as a "person who is to be engaged, is engaged or has been engaged in a remunerated activity in a State of which he or she is not a national."9

9. Art. 2(1), International Convention on the Protection of the Rights of All Migrant Workers and Members of Their Families, opened for signature Dec. 18, 1990, Annex to U.N. Doc. A/45/158 (1990). The Preamble to the Convention identifies several underlying human rights instruments, including the following agreements of the International Labor Organization, which are generally limited, like the Convention, to migrant workers: the Convention concerning Migration for Employment (No. 97), the Convention concerning Migrations in Abusive Conditions and the Promotion of Equality of Opportunity and Treatment of Migrant Workers (No. 143), the Recommendation concerning Migration for Employment (No. 86), the Recommendation concerning Migrant Workers (No. 151), the Convention concerning Forced or Compulsory Labour (No. 29), and the Convention concerning Abolition of Forced Labour (No. 105). Preamble, id. 
Although the Convention protects only workers, it applies regardless of their documented or undocumented status.

The Special Rapporteur of the United Nations Commission on Human Rights, on the other hand, has proposed that the following persons should be considered migrants: (1) Persons who are outside the territory of the State of which they are not national citizens, are not subject to its legal protection, and are in the territory of another State; (2) Persons who do not enjoy the general legal recognition of rights which is in the granting by the host State of the status of refugee, naturalized person or similar status; and (3) Persons who do not enjoy general legal protection of their fundamental rights by virtue of diplomatic agreements, visas or other agreements. United States law, however, does not make these kinds of distinctions; rather, all persons seeking admission as foreigners into the United States are deemed to be migrants. For present purposes, then, it is necessary to adopt the broad, lay definition of a migrant with which this section of the article began.

\section{The United States System of Immigration Control}

\section{A. Basic Legal Framework and Institutions}

Until the late nineteenth century, the United States had no significant laws on migration. The individual states of the Union were generally free to impose their own controls, constrained as they were by a tendency in the still-developing country to attract rather than exclude prospective contributors to the economy and settlers of the land. After the Civil War (1861-65), however, the federal government began to assume exclusive regulatory powers over immigration. During the period 1875-91, Congress gradually prohibited or regulated immigration of certain classes of persons, eventually including prostitutes, convicts, "lunatics," "idiots," paupers and others likely to become public charges, the "diseased," and polygamists. Variants or subgroups within these classes were added later. By the early twentieth century, Congress had also largely barred Japanese and Chinese immigration. What is the constitutional foundation for federal authority to regulate immigration?

The United States Constitution has no bedrock provision for allocating powers among the three branches of the government or otherwise dealing with issues of migration. The constitutional basis for the exercise of power over migration is therefore unclear. To be sure, Congress is empowered to enact laws of naturalization, but it is highly debatable whether this power implies more general powers, vis-á-vis the states, over immigration. Also, scattered constitutional provisions bearing on immigration have been interpreted to enable the federal government to enact, execute, and adjudicate migration laws. The most important of these provisions is the Interstate Com- 
merce Clause, which empowers Congress to regulate commerce among the several states and with foreign nations. Even that provision, however, is problematic because it requires a classification of human beings as commerce. Despite the precarious constitutional foundation, however, Congress has not hesitated to enact immigration legislation.

The current codification of immigration law is the Immigration and Nationality Act of $1952,{ }^{10}$ as amended. Within the executive branch of the federal government, the chief agencies of implementation are lodged in the Department of Homeland Security. Until the latter's establishment in 2003 , as an institutional response to the threat of terrorism, the Department of Justice was primarily responsible for executing the law. Other implementing agencies are found within the Department of State (visa issuance and backup in the refugee process), the Department of Labor (certification of labor petitions on behalf of prospective immigrants in certain categories), and the Department of Health and Human Services (health requirements of prospective immigrants).

The states of the Union also participate in the process of labor certification and, on a somewhat discretionary basis, cooperation in enforcement of the law. Under the preemption doctrine, however, the states may not interfere with the federal power over immigration. Thus, the states may not regulate any aspect of immigration when a federal statute has already occupied that aspect, even when the state regulation is consistent with the federal law.

\section{B. The General Theory of Control}

The United States system of immigration control has been described as an insular-Western Hemispheric system by contrast to the continental European system. ${ }^{11}$ Accordingly, the United States maintains more of a pre-admission and admission-based system of control over immigrants rather than post-admission system. Although this distinction is increasingly blurred in practice, the United States still relies on highly detailed provisions and procedures for classification of persons in advance of approved migration, visa issuance, and admission at ports of entry. On the other hand, unlike post-admission systems, the United States places much less reliance on work permits, residence permits, and national identity cards as control devices.

Indeed, the United States has no national identity card, for reasons of civil liberties. Thus, any post-entry identification of immigrants must rely, variously, on multiple documentation, including

10. 8 U.S.C. $\S \S 1101-1537$ (2000).

11. See Richard Plender, Trends in National Immigration Control, 35 INT'L \& CoMP. L.Q. 531, 535, 550-51 (1986). 
birth certificates, state drivers licenses, and social security cards. Also, historically, exit controls over departing foreigners have been weak. Until recently, there was little effort made to record all departure dates and circumstances, mostly for a lack of adequate funding.

Over the years, the United States system of control has become mixed, with elements of both the insular-Western Hemispheric model of pre-admission controls and the continental European system of post-admission controls. For example, certain categories of immigrants require labor certification; and visa holders, after their admission into the United States, must notify the government of any changes of their residence in the United States. This requirement has been particularly emphasized since $9 / 11$.

\section{Classification of Migrants}

\section{Non-immigrants}

The chart in the Annex to this article indicates that over 30 million non-immigrants were admitted into the United States in 2004. Non-immigrants are persons admitted into the United States for specific purposes, including, for example, business, pleasure, education, and temporary work. They must receive visas, typically stipulating temporary visits for fixed durations. Each class of immigrants is assigned a separate letter for purposes of visa issuance. Thus, for example, tourists are "B2" and students may be either "F" or "J." Although refugees are also admitted temporarily for a specific, humanitarian purpose, they are not classified as non-immigrants. Congress has also established temporary worker programs to accommodate worker shortages in the United States. The bracero program, in particular, was designed to attract large numbers of Mexican workers to serve emergency needs during World War II. Workers were actively recruited in Mexico to sign employment contracts for "temporary" work in the United States. The program lasted several decades and resulted in large numbers of more or less permanent visa overstays.

\section{Immigrants}

The Immigration and Nationality Act defines immigrants as all aliens (that is, non-citizens), except nonimmigrant aliens. Other fundamental terms in the immigration lexicon of the United States include "resident alien" (all persons living in the United States who are not citizens or nationals) and LPRs (aliens who are "lawfully admitted for permanent residence"). By virtue of lawful admittance, immigrants are accorded the privilege of residing permanently in the United States and may be eligible for citizenship (within five years, but an LPR married to an American citizen is eligible to become a citizen in three years). 
Immigrant visas are issued under four headings: family-related immigrants, employment-based immigrants, refugees (including asylees), and diversity immigrants (in the sense of correcting imbalances of nationality in practice). Immediate relatives are exempt from visa requirements. Both the family-related and employmentbased headings are further specified. The family-related heading is divided into prioritized preference categories, generally according to the extent of consanguinity of applicants with certain classes of United States citizens and lawful permanent residents. An adjustable total of 465,000 family-based visas, not including immediate relatives, may be issued in one year. Immigrants by virtue of marriage to an American citizen or LPR and their children must satisfy a twoyear conditional residency requirement. Couples seeking to remove the condition at the end of two years must be prepared to show that they did not enter into the marriage solely to secure LPR status-the so-called "green card"-for a non-citizen spouse. They must also show, with a few exceptions, that the couple was not divorced during the two-year period.

The employment-based heading of immigrants is further specified by preference categories according to level of professional prowess and occupational skills. Numerical quotas are assigned to all employment-based categories and all family-related categories except immediate relatives. An adjustable total of 180,000 employmentbased visas may be issued each year. Labor certification is also required for some, but not all, of the employment-based categories. The chart in the Annex lists the total number of non-immigrants and immigrants admitted into the United States in 2004 by general categories.

\section{Adjustment of Status}

Ordinarily, with very few exceptions, non-immigrants who have entered the United States lawfully and have maintained a lawful status are entitled to adjust their status from one visa category to another or to immigrant status. Generally, eligible persons may do so without leaving the country. Of course, any person ineligible for adjustment of status-for example, someone who has overstayed their visa or accepted unauthorized employment-may simply return to their home country and apply for a new visa at the consulate in their home district.

\section{Grounds for Non-Admissibility and Removal}

The grounds for non-admissibility of applicants and undocumented entrants and removal of foreign nationals are elaborate. The grounds for non-admissibility and removal are similar but not identical, falling into five categories: immigration control (distinguishing 
persons on the basis of the legitimacy of their status under the immigration law), political and national security, criminal, economic, and public health and morals. In recent years, several ideological vestiges of the Cold War have been eliminated, such as exclusion of members or former members of the Communist Party, whereas antiterrorism and criminal grounds (particularly involving aggravated felonies and drug offenses) have been strengthened.

Unlike non-citizens applying for admission into the United States, persons already in the United States but subject to removal are generally entitled to a hearing in satisfaction of the requirements of due process. The test of what constitutes due process in a given case involves a determination of whether a life, liberty, or property interest is at stake. If so, then three factors must be balanced on a case-by-case basis:

First, the private interest that will be affected by the official action [for example, of removal from the United States]; second, the risk of an erroneous deprivation of such interest through the procedures used, and the probable value, if any, of additional or substitute procedural safeguards; and finally, the Government's interest, including the function involved and the fiscal and administrative burdens that the additional or substitute requirement would entail. ${ }^{12}$

Non-citizens are also entitled to administrative review and judicial review, in some circumstances, of removal orders.

Most persons subject to removal from the United States, however, elect to depart the country voluntarily without a removal hearing. The incentive for doing so is that a voluntary departure does not carry the risk of a formal removal (that is, deportation), with its punitive constraints on later return to the United States and, in some circumstances, total bar on return. Besides voluntary departure, discretionary relief from removal includes, first, cancellation of removal to the benefit of non-citizens who have resided in the country for extended periods of time, in order to ameliorate what otherwise would be a potentially severe effect of removal. Eligibility for cancellation of removal involves specific criteria of continuous presence in the United States for ten years and several requirements of good moral character and non-excludability. Other discretionary relief from removal includes adjustment of status, asylum, stay of removal, and parole by an executive order.

12. Mathews v. Eldridge, 424 U.S. 319 (1976). 


\section{E. Administrative and Judicial Review of Legislation and Decisions}

A cardinal doctrine of United States constitutional law is that Congress has an inherent, plenary power in matters of immigration. "[O]ver no conceivable subject is the legislative power of Congress more complete than it is [over the admission of non-citizens]." 13 The most important implication of this formidable power is to bar judicial review of legislation, with some exceptions. The courts have gone so far as to pronounce that "whatever the procedure authorized by Congress, it is due process as far as an alien denied entry is concerned."14 As a corollary, the executive branch, acting within its constitutional authority, enjoys derivative power free of judicial review. To be sure, Congress has provided for administrative review-primarily under the Administrative Procedure Act-and judicial review of executive decisions. But there is only a very limited range of administrative and judicial review available with respect to decisions on admissionthat is, of decisions by United States consular offices abroad to exclude persons from entering the country. ${ }^{15}$

The plenary power vested in Congress bars review of legislation and executive measures altogether in many cases. That is unique in American governmental practice. Even when courts exercise review powers in matters of immigration, they are deferential to the political branches. Under the federal Administrative Procedure Act, the normal standard for review of legislation is whether it is arbitrary or capricious. The normal standard for review of an executive decision or regulation is whether the decision or regulation represents an abuse of discretion.

\section{Trends in Admission and Removal of Immigrants and in Public Opinion}

\section{A. Current Migration Flows ${ }^{16}$}

Immigration to the United States reached a peak of about 1.5 million in 2000, not including non-immigrants. Between 2000 and 2004, immigration to the United States declined substantially to less than 1 million (see figures for 2004 in the Annex). Historically, the expansion and contraction of the U.S. economy seems to be the most

13. Oceanic Steam Navigation Co. v. Stranahan, 214 U.S. 320, 339 (1909). Accord, Fiallo v. Bell, 430 U.S. 787, 792 (1977) (immigration measures are "largely immune from judicial review.").

14. United States ex rel. Knauff v. Shaughnessy, 338 U.S. 537, 544 (1950).

15. See StePhen H. Legomsky, Immigration and REFugee LaW and Policy 14458, 469-85 (4th ed. 2005); James A.R. Nafziger, Review of Visa Denials by Consular Officers, 66 WASH. L. REV. 1, 25-35 (1991). 1.

16. Nina Bernstein, Decline is Seen in Immigration, N.Y. Times, Sept. 28, 2005, at 
plausible explanation of such fluctuations in migration. But anti-terrorist constraints since $9 / 11$ also may have deterred visa applicants and therefore may help explain the lower numbers in the years immediately following 9/11. Two other trends are noteworthy: the destinations in the United States of newly arrived immigrants have broadened substantially and the estimated number of undocumented (largely Mexican) migrants entering the United States each year now exceeds the number of documented immigrants.

\section{B. Enforcement of Immigration Laws ${ }^{17}$}

In 2004, immigration violations replaced drug crimes as the leading category of federal prosecutions. So dramatic is the rise in the number of prosecutions under immigration laws that they more than doubled between $2002(16,300)$ and $2004(38,000)$. The data reveal that the trend is attributable to a deliberate shift in priorities by federal law-enforcement agencies, largely in response to the threat of terrorism after 9/11. Drug investigation has been markedly diverted to investigation of immigration violations.

\section{Public Opinion}

In projecting trends in United States immigration law, public opinion is an important factor. Fundamentally, even after 9/11, Americans have favored a steady flow of immigration in the nation's economic and other interests. ${ }^{18}$ The country has steadfastly kept its arms open to prospective migrants. The devil, however, has been in the details of control. Given the salience of immigration issues and the sensitivity of people toward new neighbors, fluctuating public attitudes over the years have been unusually influential in shaping adjustments of both procedure and substance in the law. Sometimes the public wants a more open door to migrants, other times more of a closed door. Congress has typically responded in cycles of liberality and restriction within acceptable margins of appreciation.

A 2005 poll of public opinion concerning United States foreign policy overwhelmingly indicated disenchantment with efforts to pro-

17. Eric Lichtblau, Prosecutions in Immigration Doubled in Last Few Years, N.Y. Trmes, Sept. 29, 2005, at A27. See also Eric Lipton, Report Finds U.S. Failing on Overstays of Visas, N.Y. Times, Oct. 22, 2005 (reporting on the serious problem of an estimated 3.6 million visa violators and lack of enforcement to pursue them).

18. The United States is a nation of immigrants with the motto "e pluribus unum" (from many one), a reminder that Americans share the experience of themselves or their forebears leaving another country to begin anew in the US. [footnote omitted] Most Americans believe that immigration is in the national interest, and this belief did not change after the September 11, 2001 terrorism attacks, as political leaders consistently drew a distinction between immigrants and terrorists.

Philip L. Martin, Sustainable Migration Policies in a Globalizing World 16 (2003). 
tect U.S. borders from undocumented migration. To be sure, that has been a persistent concern throughout American history. Its implications for legal reform are therefore uncertain. What is significant, however, is that, according to the 2005 poll, only $25 \%$ of the public assigned good grades ("A" or " $B$ ") to the federal government in its enforcement of border controls over immigration. That low level of approval ranked third from the bottom of twenty stated expectations about United States foreign policy, ranging from "hunting down antiAmerican terrorists" to "making international trade agreements that benefit the U.S."

\section{Treatment of Migrants in the United States}

\section{A. Constitutional Framework}

International human rights law requires all states to comply with minimum standards for treatment of non-citizens. Special standards apply to refugees and IDPs, as noted earlier. Aside from these requirements, the treatment of non-citizens in the United States is largely defined by the Bill of Rights and later amendments in the United States Constitution. Although the long line of jurisprudence testing the parameters of such constitutional protection is beyond the scope of this article, a brief summary of it may be helpful for the purpose of comparison.

The Restatement (Third) of Foreign Relations Law summarizes the accumulated authority under the Fifth and Fourteenth Amendments to the U.S. Constitution as follows:

(1) An alien in the United States is entitled to all the guarantees of the Constitution of the United States other than those expressly reserved for citizens.

(2) Under Subsection (1), an alien in the United States may not be denied the equal protection of the laws, but equal protection does not preclude reasonable distinctions between aliens and citizens, or between different categories of aliens. ${ }^{19}$

The federal government's powers to discriminate on the basis of alienage, especially in matters of employment, are broader than those of the states. In reviewing the extent of such federal powers, the courts apply the Fifth Amendment's due process clause. ${ }^{20}$ This is manifest in certain provisions of the immigration law itself, which may impose a durational residence on non-citizens-for example, three years from the date of a non-citizen's admission into the United States-to establish eligibility for welfare and other benefits.

19. Restatement (Third) of the Law of Foreign Relations $\$ 722$ (1987)

20. See Mathews v. Diaz, 426 U.S. 67 (1976). 
The Fourteenth Amendment to the U.S. Constitution forbids the states of the Union from denying "the equal protection of the laws" to all "persons" within their jurisdictions. As early as 1886, in Yick Wo v. Hopkins, ${ }^{21}$ the United States Supreme Court confirmed that "[t]he Fourteenth Amendment of the Constitution is not limited to citizens."22 Subsequent decisions have defined the extent of this equal protection and therefore the extent to which the states may constitutionally enact or adopt other discriminatory measures on the basis of alienage.

A "strict scrutiny" by courts of state discrimination based on suspect classifications of persons-race and religion, for example-has been extended to instances of discrimination on the basis of alienage. There are some exceptions, however. The seminal case law of the 1970 s and $1980 \mathrm{~s}$ is especially instructive. In Cabell $v$. ChavezSalido, ${ }^{23}$ for example, the Court upheld a California statute barring non-citizens from employment as "peace officers." Three lawfully admitted permanent resident aliens who had been denied jobs under the statute challenged it on equal protection and statutory grounds. The Court based its decision solely on an equal protection analysis, relying on Foley $v$. Connelie, ${ }^{24}$ which upheld a New York statute requiring state police officers to be U.S. citizens.

Cabell falls in a line of cases that entails something of a retreat from the broad grant of equal protection rights for aliens begun by the Court in Graham v. Richardson. ${ }^{25}$ There the Court implied that only in very few areas could a state permissibly discriminate against aliens who, as a discrete and insular minority, were afforded a judicial review standard of strict scrutiny. Strict scrutiny no longer is required of state actions, however, where they can be reasonably characterized as having been taken in order to "preserve the basic conception of a political community."26

Another pertinent constitutional issue besides equal protection is whether a state, by imposing certain conditions on its residents related to immigration, infringes upon powers otherwise reserved to the federal government. For example, the California Labor Code prohibits employers from knowingly employing aliens not entitled to residence in the United States if such employment would have an adverse effect on lawful resident workers. In DeCanas $v$. Bica, ${ }^{27}$ the United States Supreme Court held that those provisions do not vio-

21. 118 U.S. 356 (1886).

22. Id. at 369 .

23. 454 U.S. 432 (1982).

24. 435 U.S. 291 (1978).

25. 403 U.S. 365 (1971).

26. See Sugarman v. Dougall, 413 U.S. 634, 647 (1973).

27. 424 U.S. 351 (1976). 
late the doctrine of federal preemption or infringe on the exclusive congressional power over naturalization and immigration.

Very often, however, the federal preemption issues are set in a more complex context, such as that of state benefits to undocumented workers. In Hoffman Plastic Compounds $v$. National Labor Relations Board, ${ }^{28}$ the United States Supreme Court held that federal immigration policy precluded the Board from awarding back wages to undocumented workers who had been fired in violation of federal law. The rationale was that to do so would trench upon explicit statutory prohibitions that are critical to federal immigration policy. In Majlinger v. Cassino Contracting Corp. ${ }^{29}$ however, the New York Supreme Court ruled, on review of a tort action, that an undocumented worker was entitled to recover back pay, regardless of a federal law prohibiting the hiring of undocumented workers. The New York court held that the Hoffman rule did not extend to state court personal injury and workplace safety cases or common law torts. The court reasoned that there is no public policy interest in denying recovery to undocumented workers. To the contrary, doing so would defeat a fundamental interest of the state in encouraging employers to ensure workplace safety for all workers, regardless of their citizenship or immigration status.

\section{B. Anti-Terrorist Measures}

After the 9/11 attack, the 2001 Foreign Terrorists Tracking Force was formed. ${ }^{30}$ Numerous non-citizens were arrested and detained. Some were charged with criminal activity pending investigation, while some were held as material witnesses. Some were deported for use of fraudulent documents, illegal entry, overstaying visas, and other immigration-related offenses. United States courts had to hear their claims concerning their civil rights and liberties.

A second legislative initiative, the USA PATRIOT Act of 2001, gave the Attorney General the power to detain non-citizens suspected of terrorism. The Attorney General was required to charge them with a crime, initiate deportation, or release them within seven days. Administrative regulations have been expanded to let a detainee be held 48 hours without charge for an additional "reasonable period of

28. 535 U.S. 137 (2002).

29. 802 N.Y.S.2d 56, (2005).

30. When the then Attorney General introduced the new measures, he said as follows:

We will arrest and detain any suspected terrorist who has violated the law. If suspects are found not to have links to terrorism or not to have violated the law, they will be released. But terrorists who are in violation of the law will be convicted, in some cases deported, and in all cases be prevented from further harm to Americans.

Lawyers Committee on Human Rights, A Year of Loss, ch. 3, at 12 (2002). 
time" in extraordinary circumstances. Certification of a suspected terrorist must be reviewed every six months to be renewed or revoked. The government has used the detention power sparingly.

The National Security Entry-Exit Registration System (NSEERS) for members of stipulated groups, also known as special registration, provides an improved legal basis for tracking possible terrorists. Non-immigrants who pose "national security risks," as determined by federal government, are subject to fingerprinting, photographing, and special registration. The stipulated groups are largely defined as males over the age of sixteen from heavily Muslim countries of origin. These three initiatives are among the most important legislative and executive actions that were taken after 9/11 in response to the new threat of terrorism.

\section{Border Issues}

Historically, the longest unfortified national borders in the world have been those between the United States and its neighbors, Canada and Mexico. Even the fencing that was installed in recent years along the Mexican border as well as the enlistment of volunteer patrols in heavily trafficked areas have only a very limited geographical range. The United States-Mexican border is also the longest, if not the only major one between a developed and a developing country. Although the U.S.-Canadian border and other ports of entry, including airports, have assumed greater significance since $9 / 11$, the U.S.Mexico border remains the focus of immigration control. Border issues involve the influx of undocumented migrants, the process of admission at designated stations along the border, patrolling for and removal of non-admissible migrants, and, more recently, the threat of terrorist infiltration.

It is estimated that some 11 million undocumented aliens reside in the United States, a majority of whom are Mexican. Their presence bespeaks the intractability of border controls and the ease of seasonal and repeated migration back and forth across the border. The "push" and "pull" factors of migration are apparent along the border, day in and day out. From time to time, Congress has granted amnesty to undocumented migrants, thereby enabling them to become LPRs and eventually citizens. The federal government has also suspended sanctions against employers of undocumented aliens when migrant workers are especially needed, for example, in the aftermath of Hurricane Katrina.

In order to enter the United States in the first place, however, many undocumented migrants have trekked through the California and Arizona deserts in oppressive heat, rubbed garlic on their skin to ward off rattlesnakes, swum across the All-American Canal and Rio Grande River, or spent days hiking over the mountain ranges in 
frigid weather. They have suffocated in the airless trucks of smugglers, died in vehicle crashes, been struck by lightning, or drowned. Too often migrants have been preyed upon by their Mexican handlers (often called "coyotes"), U.S.-based contractors (frequently non-citizens), and criminals who assault, rob, and kill them. In sum, desperate migrants risk their lives crossing unguarded and desolate frontiers to avoid stepped-up border patrols in populated areas.

In reviewing the constitutionality of law enforcement measures along the border, under the immigration law, the United States Supreme Court has delineated margins of authority and established standards of search and seizure. In one of its decisions, United States $v$. Brignoni-Ponce, ${ }^{31}$ the Court acknowledged that undocumented aliens "are vulnerable to exploitation because they cannot complain of substandard working conditions without risking deportation"32 and that they "are frequently victims of extortion, violence and sharp practices" after giving themselves over to professional "alien smugglers."33

Advocacy groups have criticized border patrol policies, which they claim are responsible for increasing the death toll and injury of migrants at the borders. Whether this argument is right or wrong is less important than efforts at all levels of government to address the plights of migrants at the border, despite the difficulty of separating militant terrorists from innocent migrants.

The Preamble to the Convention on Migrant Workers ${ }^{34}$ expresses an intent "to establish norms which may contribute to the harmonization of the attitudes of States through the acceptance of basic principles concerning the treatment of migrant workers and members of their families." Progress, it is acknowledged, has already been made on a regional and bilateral basis. The Preamble's accent on "the importance and usefulness of bilateral and multilateral agreements" (including the Convention itself) provides a formal model of international cooperation for helping resolve not only border-related problems but also broader issues of migration.

31. 422 U.S. 873 (1975).

32. Id. at 879 .

33. Id. at 904

34. Supra note 9. 


\section{Annex}

\section{United States Department of Homeland Security, 2004 Yearbook of ImMigration STATISTICS}

\section{A. Non-immigrants Admitted by Class of Admission}

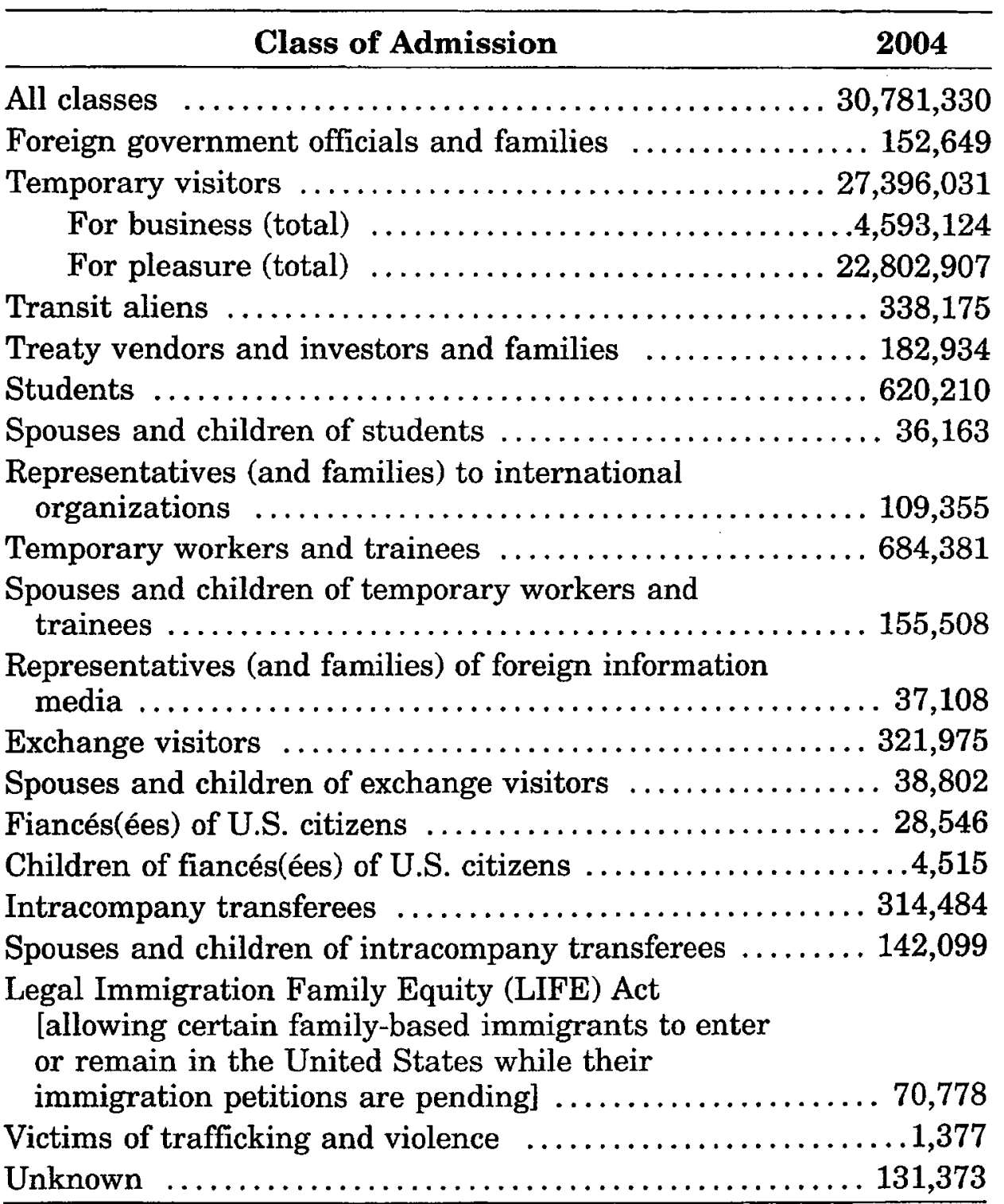




\section{B. Immigrants Admitted by Type and Class of Admission}

\section{Type and class of admission}

Total, all immigrants ............................9946,142

Total, subject to annual numerical limit ............423,373

Total, not subject to annual numerical limit .......... 513,769

Immediate relatives of U.S. citizens ............. 406,074

Children born to alien residents abroad .............. 707

Refugees ..................................6 61,013

Other asylees ............................... 201

Other cancellation of removal [Salvadorian,

Guatemalan, and former Soviet bloc nationals] .....30,136

NACARA [Nicaraguan Adjustment and Central

American Relief Act] .........................2,292

HRIFA [Haitian Refugee Immigration Fairness Act] ...2,451

Parolees, Soviet and Indochinese ................. 7,117

Other ...................................., 378

Total, family preferences ......................214,335

Total, 1st preference [unmarried sons and daughters of

U.S. citizens] .............................. 26,480

Total, $2 \mathrm{~d}$ preference [spouses and unmarried sons and daughters of lawful permanent residents] .......... 93,609

Total, $3 \mathrm{~d}$ preference [married sons and daughters of lawful permanent residents] . .................. 28,695

Total, 4th preference [brothers and sisters of over-age21 U.S. citizens] $\ldots \ldots \ldots \ldots \ldots \ldots \ldots \ldots \ldots \ldots \ldots \ldots \ldots, 65,671$

Total, employment preferences $\ldots . \ldots \ldots \ldots \ldots \ldots \ldots \ldots$. 155,330

Total, 1st preference [persons of extraordinary ability, outstanding professors and researchers] ............ 31,291

Total, $2 \mathrm{~d}$ preference [members of professions with advanced degrees and persons with exceptional

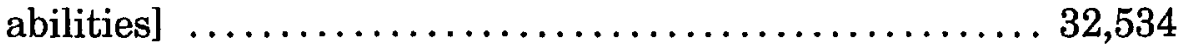

Total, 3d preference [other professionals with a baccalaureate degree, skilled laborers, and other workers]

Total, 4th preference Imiscellaneous employment based, such as religious ministers and broadcast employees] ..................................5,407

Total, 5th preference lemployment-creating entrepreneurs] ............................... 129 